\title{
KEPEMIMPINAN DAN PENJAMINAN MUTU; Peran Kepala Sekolah dalam Menunjang Penjaminan Mutu SMA YP 17 Surabaya
}

\author{
Usman'; Mohammad Baihaqi2 \\ 'Institut Agama Islam Negeri Pontianak; ${ }^{2}$ SDIT Nurul Rahmah Bangkalan
}

\begin{abstract}
ABSTRAK
Penjaminan dan pengembangan mutu sebuah lembaga pendidikan bergantung kepada kualitas kepala sekolah sebagai pemimpin pendidikan. Oleh sebab itu, kepala sekolah dituntut lebih kreatif, inovatif dan dinamis seiring dengan perubahan masyarakat yang semakin cepat dan terbuka. Penelitian ini bertujuan untuk menganalisis peran kepemimpinan kepala sekolah dalam menunjang penjaminan mutu di SMA YP 17 Surabaya. Penelitian ini merupakan penelitian kualitatif diskriptif dengan pendekatan studi kasus. Dari hasil penelitian dapat disimpulkan bahwa dalam menunjang penjaminan mutu, kepemimpinan kepala SMA YP 17 Surabaya didukung oleh karakter tanggung jawab yang kuat, keberanian dalam mengambil keputusan, dan keikutsertaan dalam melaksanakan kebijakan. Kepala sekolah telah melakukan beberapa upaya penting dalam menunjang penjamianan mutu lembaga dengan mengembangkan kurikulum, Sumber Daya Manusia, sarana prasarana dan meningkatkan peran serta masyarakat. Secara manajerial, pengembangan mutu lembaga didukung dengan koordinasi yang baik dengan civitas akademik dan adanya kebersamaan dalam pengelolaan kurikulum dan pembelajaran. Agar penjaminan mutu lebih efektif, kepala sekolah harus melakukan evaluasi secara periodik dari setiap program yang telah dilaksanakan. Tujuannya adalah untuk mengukur tingkat keberhasilan dan mengetahui kekurangan program yang dilaksanakan. Selanjutnya, kepala SMA YP 17 perlu melakukan sosialiasi lembaga yang lebih massif kepada masyarakat. Hal ini sebagai upaya untuk meningkatkan partisipasi masyarakat dalam upaya pengembangan mutu sekolah ke depan.

Kata Kunci: Kepemimpinan, Kepala Sekolah, Kebijakan, Penjaminan Mutu.
\end{abstract}

\section{ABSTRACT}

The quality assurance and development of an educational institution depends on the quality of the headmaster as an educational leader. Therefore, the headmaster are required to be more creative, innovative and dynamic in line with changes in society that are increasingly fast and open. This study aims to analyze the role of principal leadership in supporting quality assurance at SMA YP 17 Surabaya. This research is a descriptive qualitative research with a case study approach. From the results of the study it can be concluded that in supporting quality assurance, the leadership of the head of SMA YP 17 Surabaya is supported by the character of strong responsibility, courage in making decisions, and participation in implementing policies. The headmaster has made several important efforts in supporting the quality assurance of the institution by developing the curriculum, human resources, infrastructure and increasing community participation. In managerial terms, the development of the quality of the institution is supported by good coordination with the academic community and the existence of togetherness in curriculum management and learning. In order for quality assurance to be more effective, the headmaster must periodically evaluate every program that has been implemented. The aim is to measure the level of success and find out the deficiencies of the program being implemented. Furthermore, the headmaster needs to conduct more massive socialization of the institution to the community. This is an effort to increase community participation in efforts to develop the quality of schools in the future.

Keywords: Leadership, Headmaster, Policy, Quality Assurance. 


\section{A. Pendahuluan}

Untuk mencapai Tujuan Pendidikan Nasional, lembaga pendidikan harus didukung oleh kepemimpinan kepala sekolah dalam mengembangkan lembaga pendidikan yang berkualitas dan efektif. ${ }^{1}$ Kepemimpinan yang efektif merupakan realisasi perpaduan bakat dan pengalaman kepemimpinan dalam situasi yang berubahubah karena berlangsung melalui interaksi antar sesama manusia. Kualitas kepemimpinan menentukan untuk mencapai keberhasilan suatu lembaga pendidikan. Karena kepemimpinan yang sukses itu mampu mengelola lembaga yang dipimpinnya, mampu mengantisipasi perubahan, mampu mengoreksi kekurangan dan kelemahan serta sanggup membawa lembaga pada tujuan yang telah ditetapkan. ${ }^{2}$

Kepemimpinan dan pemimpin dibutuhkan untuk mengefesienkan setiap langkah atau kegiatan. Dan hanya pemimpin-pemimpin yang bersedia mengakui bakat-bakat, kapasitas, inisiatif dan kemauan baik dari para pengikutnya (rakyat, anak buah, individu dan kelompok-kelompok individu yang dipimpin) untuk berinisiatif dan bekerja sama secara kooperatif, hanya pemimpin sedemikian inilah yang mampu menjamin kesejahteraan lahir batin masyarakat luas. ${ }^{3}$ Sekaligus, pemimpin seperti ini sanggup mempertinggi produjktifitas dan efektifitas usaha bersama. Oleh karena itu pemimpin merupakan faktor kritis (crucial factor) yang dapat menentukan maju mundurnya suatu lembaga.

Kepemimpinan kepala sekolah berpengaruh terhadap pelaksanaan pendidikan dan pengajaran khususnya terhadap pembinaan guru dalam melaksanakan tujuannya. Kepemimpinan kepala sekolah yang berkualitas akan mempengaruhi proses belajar mengajar di sekolah termasuk SMA YP 17 Surabaya. Dengan situasi tersebut akan memunculkan tipe atau pola kepemimpinan kepala sekolah dalam segala aktivitasnya mempunyai peranan yang penting sebagai langkah menentukan efektif tidaknya kepemimpinan di sekolah.

Sekolah sebagai salah satu bagian sistem pendidikan Nasional tentu memerlukan perhatian dan pengelolaan secara serius. Karena itu, kepemimpinan sekolah ke depan dengan perubahan masyarakat yang semakin cepat dan terbuka menuntut kemampuan yang lebih kreatif, inovatif dan dinamis. Kepala sekolah yang

${ }^{1}$ Nanang Budianto, “Kepemimpinan Pendidikan dalam Total Quality Management”, Jurnal Falasifa Vol. 2 No. 1 (2011).

2 N. Andrew Cohen \& Jeewhan Yoon, "Who Makes Whom Charismatic? Leadership Identity Negotiation in Work Teams”, Journal of Leadership \& Organizational Studies, Vol. 28 Issue 1, February 2021.

${ }^{3}$ Mukhtar, "Strategi Kepala Sekolah Dalam Meningkatkan Kinerja Guru Pada Smp Negeri Di Kecamatan Masjid Raya Kabupaten Aceh Besar", Jurnal Magister Administrasi Pendidikan, Volume 3, No. 3, (Agustus 2015). 
sekedar bergaya menunggu dan terlalu berpegang pada aturan-aturan birokratis dan berfikir secara struktural dan tidak berani melakukan inovasi untuk menyesuaikan tuntutan masyarakatnya, akan ditinggalkan oleh peminatnya. Pada masyarakat yang semakin berkembang demikian cepat dan didalamnya terjadi kompetisi secara terbuka selalu dituntut kualitas pelayanan yang berbeda dengan masyarakat sebelumnya. ${ }^{4}$

Berdasarkan pertimbangan-pertimbangan di atas, Adler, menguatkan bahwa kepemimpinan kepala sekolah sangat berperan aktif untuk mempersiapkan generasi masa depan dalam menghadapi tantangan perubahan zaman. ${ }^{5}$ Kepala sekolah sebagai pemimpin pendidikan tidak saja dituntut menguasai teori kepemimpinan, tetapi ia harus terampil menerapkan dalam situasi praktis di area kerja. Idealnya, seorang pemimpin pendidikan di samping memiliki bekal kepemimpinan dari teori dan pengakuan resmi yang bersifat ekstern tapi juga pembawaan potensial yang dibawa sejak lahir. ${ }^{6}$

Lembaga pendidikan yang telah mengusahakan penjaminan mutu, berarti melaksanakan hal-hal yang bersifat mendasar (the basic), dan mengembangkan pendidikan yang mengarah ke hal-hal yang penting. Pendidikan yang menekankan halhal yang mendasar ini sangat diperlukan untuk menempuh kemampuan para siswa mengikuti pendidikan tambahan atau pelatihan ulang (retrainability) dan ketrampilan (skill). ${ }^{7}$ Tujuan sekolah menerapkan ini agar anaknya kelah mempunyai bekal yang cukup secara agama dan pengetahuan umum sehingga dapat melanjutkan pendidikan ditengah-tengah masyarakat, sebagai sosok generasi yang utuh.

Kepala sekolah sebagai pemimpin lembaga pendidikan dengan berbagai fungsi dan perannya, tentunya orang yang penting bertanggung jawab atas segala aktifitasnya serta maju atau mundur, baik atau jelek, kualitas atau tidaknya sebuah pendidikan yang dipimpinnya. Maka tidak mengherankan bila dia disebut sebagai orang pertama dan utama atas eksistensinya serta mutu pendidikan yang dipimpinnya. Terlebih, dalam menghadapi kompetesi yang begitu ketat, baik antara lembaga pendidikan maupun outputnya, maka langkah-langkah dan inovasi pendidikan merupakan suatu yang tidak bisa ditawarkan lagi.

\footnotetext{
${ }^{4}$ Imam Suprayogo, Pendidikan Berparadigma Al-Qur'an (Malang: Aditya Media Bekerjasama Dengan UIN Malang Press, 2004), 212.

${ }^{5}$ M. Adler, et., al, Devolved school management in secondary schools in Scotland (Edinburgh: Department of Politics, University of Edinburgh, 1997).

${ }^{6}$ Lihat, Alexander Astin, Achieving Educational Excellence (San Francisco: Jossey Bass, Inc Publishers, 1985).

${ }^{7}$ European Commission, Assuring Quality in Education: Policies and Approaches to School Evaluation in Europe. Eurydice Report (Luxembourg: Publications Office of the European Union, 2014).
} 


\section{B. Pembinaan dan Peningkatan Mutu Lembaga Pendidikan}

Sekolah merupakan salah satu lembaga pendidikan yang memiliki eksistensi yang penting dalam mencerdaskan kehidupan Bangsa. Pembinaan dan pengembangan lembaga pendidikan Islam merupakan salah satu upaya untuk meningkatkan kualitas out put pendidikan yang selama ini dikeluhkan oleh masyarakat maka dari itu pembinaan dan pengembangan ini meliputi : Pertama, Pemberdayaan Swasta. Sekolah swasta adalah akar dari pertumbuhan lembaga pendidikan di lingkungan Kementerian Agama dan Kementerian Pendidikan dan Kebudayaan, dan merupakan bagian terbesar dari populasi sekolah di Indonesia (95\%). ${ }^{8}$

Kedua, Peningkatan Kualitas. Dalam upaya memacu perkembangan kualitas pendidikan sekolah maka perlu diterangkan program strategis yang mampu mengangkat citra sekolah dalam dunia pendidikan di Indonesia. Program stategis itu meliputi: Sekolah Model, Sekolah Terpadu, Sekolah Unggul, Standar Kompetensi Kurikulum, Pendidikan Dan Pelatihan, Penataran, dan Penyediaan Bahan Atau SumberSumber Belajar Guru dan Siswa. ${ }^{9}$

Sekolah memiliki peranan yang cukup besar dalam rangka mencerdaskan kehidupan bangsa, karena sekolah lahir dari prakarsa dan partisipasi masyarakat melalui niat suci. Kelahiran sekolah di latar belakangi oleh keinginan untuk menyeimbangkan antara ilmu agama dan ilmu umum. Eksistensi sekolah dalam kancah Dunia pendidikan semakin terjaga, hal ini terbukti dengan semakin berkembangnya sekolah baik segi kualitas maupun kuantitas peningkatan kualitas baik dari segi input pendidikan, proses pendidikan maupun output pendidikan merupakan suatu keharusan bagi sekolah. Maka dari itu lembaga-lembaga pendidikan yang berciri khas Islam harus selalu meningkatkan kualitas pendidikanya, sehingga lembaga-lembaga tersebut dapat menghasilkan manusia-manusia unggulan yang dapat bersaing dengan bangsa lain.

Adapun sebagai usaha kepala sekolah dalam pengembangan lembaga pendidikan di antaranya:

1. Pengembangan Administrasi Kurikulum

Kurikulum adalah serangkaian kegiatan dan pengalaman belajar yang direncanakan, diorganisasikan dan diprogramkan untuk mencapai tujuan pendidikan. Penyusunan suatu program pendidikan di sekolah bergantung kepada nilai-nilai, teori, yang bertalian pada tujuan, sifat dan pengajaran pengetahuan

\footnotetext{
${ }^{8}$ Lihat, Cyril Poster, Gerakan Menciptakan Sekolah Unggul (Jakarta: Lembaga Indonesia Adidaya, 2000).

9 Indrafahrudi, Pengantar Bagaimana Memimpin Sekolah yang Baik, 91. 
serta konsep tentang belajar, di mana ketiga komponen ini saling berhubungan. ${ }^{10}$ Kegiatan administrasi sekolah diarahkan kepada pencapaian tujuan pendidikan yaitu tujuan pendidikan yang tergambar dalam kurikulum sekolah masing-masing. Administrasi kurikulum mencakup penyususnan kurikulum pembinaan kurikulum, pelaksanaan kurikulum, seperti antara lain pembagian tugas mengajar pada guru, penyusunan silabus atau rencana pengajaran harian dan mingguan. ${ }^{11}$

Dengan demikian kurikulum suatu sekolah pada dasarnya merupakan suatu alat untuk mencapai tujuan pendidikan. Apabila tujuan pendidikan tidak atau kurang berhasil orang akan cenderung untuk meninjau kembali kurikulum. Karena kurikulumnyalah yang berkaitan dengan tujuan pendidikan, kualitas pendidikan dan relevansi hasil pendidikan dengan masyarakat yang ada. Kurikulum yang tidak sesuai dengan perkembangan ilmu pengetahuan dan teknologi, tidak sesuai dengan tuntutan masyarakat serta tenaga kerja perlu ditinjau dan direnovasi.

Dalam melaksanakan kurikulum yang begitu luas ini, kepala sekolah sebagai supervisor harus mampu mendelegasikan wewenang dan tanggung jawab kepada guru dan mengawasinya serta dapat menciptakan iklim kerjasama yang harmonis dan saling bertanggung jawab atas tugas masing-masing.

2. Peningkatan Kualitas dan Kuantitas Sarana dan Prasarana

Suatu proses mungkin tidak akan berhasil dengan mengabaikan adanya sarana dan prasarana. Kalaupun ada bukanlah keberhasilan yang sempurna. Dengan kenyataan inilah dapat dikatakan bahwa sarana dan prasarananya mempunyai kedudukan yang sangat penting. Sarana sekolah adalah semua peralatan dan perlengkapan yang langsung di gunakan dalam proses atau kegiatan pendidikan misalnya gedung sekolah, ruangan, meja, kursi, alat peraga dan lain sebagainya. Sedangkan prasarana adalah merupakan bagian dari semua komponen yang secara tidak langsung menunjang proses belajar mengajar atau proses pendidikan sekolah misalnya tata tertib sekolah, jalan menuju kesekolah dan lain sebagainya. Sarana dan prasarana merupakan bagian dari alat pendidikan yang sangat penting guna menunjang keberhasilan pendidikan. Oleh karena itu perlu sekali adanya pengelolaan pendidikan yang baik, sebagaimana dikatakan bahwa suatu sekolah

10 Zaini Tamin AR, “Dinamika Perkembangan Kurikulum Pendidikan Pesantren; Satu Analisis Filosofis”, ELBANAT: Jurnal Pemikiran dan Pendidikan Islam, Vol. 8 No. 1 (2018): 1-21.

${ }^{11}$ Suryo Subroto, Dimensi-dimensi Administrasi Pendidikan di Sekolah (Jakarta: Bina aksara, 1984), 31. 
dapat berhasil atau berjalan dengan baik dan lancar apabila pengelolaan sarana dan prasarana itu baik. ${ }^{12}$

3. Pengembangan Sumber Daya Manusia

Dalam dunia pendidikan Islam, pendidik adalah orang-orang yang bertanggung jawab terhadap perkembangan anak didik dengan mengupayakan perkembangan seluruh potensi anak didik, baik potensi afektif, potensi kognitif, maupun potensi psikomotorik. Pendidik sebagai salah satu faktor yang sangat penting dalam pendidikan perlu ditingkatkan kualitasnya. Di sisi lain, peserta didik merupakan individu yang selalu bertumpu dan berkembang. Untuk itu agar proses belajar mengajar dapat berjalan secara aktif maka pendidik perlu memiliki pengetahuan yang mendalam tentang hakikat peserta didik sehingga dalam melaksanakan pendidikan tidak mengalami kesulitan. Sehingga usaha-usaha yang akan dilakukan adalah seperti mengaktifkan peserta didik, membentuk kelompok belajar, mengadakan ekstra kurikuler, mengadakan pengalaman langsung. Dalam lembaga pedidikan, tenaga kerja kepegawaian merupakan tenaga teknis atau tenaga profesional atau tenaga edukatif, yakni personal pelaksana proses belajar mengajar dan kegiatan kependidikan lainnya. Kepegawaian juga merupakan personel yang tidak langsung bertugas mewujudkan proses belajar mengajar, antara lain meliputi pegwai tata usaha, pegawai laboratorium, keuangan, sopir, psuru, jaga malam, pegawai perpustakaan dan lain-lain. ${ }^{13}$

Dalam rangka meningkatkan efisien kerja, masalah pembinaan pegawai menempati kedudukan yang penting, program pembinaan pegawai meliputi aspek yang cukup luas antara lain mengenai peningkatan kemmpuan kerjanya, peningkatan dedikasi, moral dan disiplin kerja pengarahan dan pembentukan motif kerja yang objektif. Peningkatan kemampuan dan kemahiran kerja dapat ditempuh dengan jalan menambah pengetahuan dan laihan-latihan bagi para personal melalui penataran/ up-grading, tugas belajar, latihan kerja (job training) dilingkungan sendiri atau lingkungan lain dan didalam atau diluar negeri. ${ }^{14}$

4. Meningkatkan Peran Serta Masyarakat

Suatu lembaga pendidikan tidak akan berhasil dalam pendidikan tanpa dukungan masyarakat. Demikian pula masyarakat, memerlukan lemabga pendidikan guna mewriskan nilai-nilai yang ada dimasyarakat. Hubungan sekolah dan

\footnotetext{
12 R. Ahmadi, Pengantar Pendidikan (Yogyakarta: Ar-Ruzz Media, 2015).

13 Hadari Nawawi, Administrasi Pendidikan (Jakarta: Gunung Agung), 165.

14 Ibid., 67.
} 
masyarakat adalah suatu proses komunikasi antara sekolah dan masyarakat dengan maksud meningkatkan pengertian warga masyarakat tentang kebutuhan dan praktek pendidikan serta mendorong minat dan kerja sama dalam usaha memperbaiki sekolah. Sekolah didirikan oleh masyarakat untuk meneladani kepentingan masyarakat. Sekolah berfungsi konservatif, inovatif dan selektif.

Mengingat begitu pentingnya hubungan antara sekolah dengan masyarakat, maka penting direalisir berbagai bentuk dan cara pelaksnaannya. Beberapa bentuk atau cara yang telah dikenal adalah: Open door politics, atau pembinaan kesempatan pada orang tua murid berkunjung ke sekolah untukmembicarakan sekolah khususnya yang terjadi pada anaknya, home visiting atau kunjungan sekolah ke rumah murid, dan penggunaan resources persons. ${ }^{15}$

\section{Karakter Ideal Kepemimpinan Kepala Sekolah}

Kepemimpinan yang dimiliki seseorang dalam suatu organisasi sangat menentukan berhasil tidaknya organisasi itu mencapai tujuan yang telah ditentukan. ${ }^{16}$ Tugas terpenting dan terutama dari seseorang pemimpin ialah memimpin orang, memimpin pelaksanaan pekerjaan dan menggerakkan sumber-sumber material.

Salah satu fungsi dari kepala sekolah ialah sebagai pemimpin pendidikan yang menjalankan “Educational Leadership", sebagai kepala sekolah tidak melakukan tindakan-tindakan yang mencerminkan kepemimpinan otoriter, tetapi sebagai pendukung dan pembela demokrasi yang menjiwai segenap tindakan kepemimpinannya.

“..Kepemimpinan selain mengenai orang lain senantiasa di dalam situasi hubungan antar manusia, secara psikologis mempengaruhi perilaku pemimpin. Aspek ini tidak kalah penting dengan aspek yang lain seperti kecakapan-kecakapan organisatoris dan teknis yang dimiliki seorang pemimpin. Kepemimpinan kepala SMA YP 17 Surabaya selalu diangkat berdasarkan prestasi dan pengabdiannya." 17

Berdasarkan interview di atas, maka dapat diketahui bahwasannya dengan kepemimpinan kepala sekolah di SMA YP 17 Surabaya diangkat berdasarkan dengan prestasi dan pengabdiannya. Apalagi secara psikologis seperti kecakapan organisatoris

15 Baca, S. P. Robbins, Organizational behavior: Concepts, Controversies, applications (8th ed) (Upper Sadlle River, NJ: Prentice-Hal, 1998).

16 Zaini Tamin AR, "PESANTREN DAN POLITIK (Sinergi Pendidikan Pesantren Dan Kepemimpinan Dalam Pandangan KH. M. Hasyim Asy'ari)", Jurnal Pendidikan Agama Islam (Journal of Islamic Education Studies), Vol. 3, No. 2 (2015).

17 Hasil wawancara dengan Bapak Drs. R. Djoko Suksmono, MM, selaku ketua Yayasan Pendidikan Tujuh Belas (YP 17) Surabaya, pada Senin, 02 April 2018. 
dan teknis yang dimiliki seorang pemimpin dapat mempengaruhi hubungan antara bawahannya. Secara lebih terperinci, penulis menemukan bebrapa hal berikut:

1. Tingkat Pendidikan

Dalam hal pengetahuan yang luas itu kepala sekolah menyatakan sesuai karena dengan berpendidikan tinggi itu diidentikkan dengan berpengetahuan luas apalagi sebagai seorang pemimpin pendidikan di sekolah.

“..Seorang pemimpin itu tidak dapat dilihat dari pendidikan yang tinggi saja, akan tetapi juga berdasarkan dengan pengetahuan yang luas karena dengan berpengetahuan luas yang itu maka dapatlah menjadikan seorang pemimpin itu bertambah ilmunya.."18

Maka hasil dari interview tersebut dapat diketahui bahwasannya dengan berpengatuhan yang luas itu tidak diidentikkan dengan berpendidikan yang tinggi.

2. Sikap Percaya Diri

Perlu diketahui, kepercayaan pada diri sendiri merupakan salah satu modal yang sangat penting bagi seorang pemimpin di sekolah, sebaliknya tanpa adanya kepercayaan itu seorang pemimpin pendidikan akan identik dengan tindakan keragu-raguan. Kepala sekolah selalu percaya diri dalam melaksanakan tugastugasnya. ${ }^{19}$ Karena dengan kepercayaan diri tersebut dapat mengembangkan lembaga yang dipimpinnya, sebaliknya tanpa adanya kepercayaan itu seorang pemimpin pendidikan akan diidentikkan dengan tindakan kerau-raguan

Hal ini sesuai dengan hasil interview dengan Bapak Drs. Heru Santoso, M.Pd, berikut ini:

"Mengembangkan sebuah lembaga pendidikan itu seorang pemimpin harus memiliki kepercayaan diri dalam menjalankan tugasnya sebagai pemimpin lembaga. Karena dengan tidak adanya kepercayaan diri tersebut maka sebuah lembaga tidak akan menjadi maju atau berkembang.."20

Berdasarkan hasil interview tersebut, maka dapat diketahui bahwasannya kepemimpinan yang mempunyai sifat percaya diri menjadikan sebuah lembaga menjadi maju dan berkembang seperti halnya dengan adanya kerjasama dengan sebuah lembaga lain.

3. Instruksi

Sebagai kepala sekolah ia merupakan pemimpin pendidikan yang seharusnya dapat memberlakukan bawahannya sehingga mendapat kesan dirinya dan tugas-

\footnotetext{
18 Hasil wawancara dengan Bapak Ruslan, BA, selaku Waka Kurikulum SMA YP 17 Surabaya, pada Rabu, 04 April 2018.

19 Lihat, misalnya D. Bromley, Reputation, image, and impression management (Wiley: 1993).

20 Hasil wawancara dengan Bapak Drs. Heru Santoso, M.Pd, selaku Waka Kesiswaan SMA YP 17 Surabaya, pada Rabu, 04 April 2018.
} 
tugas yang diberikan penting artinya untuk mencapai tujuan. Kepala sekolah memberlakukan bawahan dan tugas-tugas yang diberikan penting artinya untuk mencapai tujuan.

“..Kepemimpinan kepala sekolah ini yang hubungannya dengan bawahan lainnya baik dalam mengelola lembaga ini, apalagi hubungannya dengan masyarakat sekitar minim sekali atau kurang dekat, namun beliau ini konsentrasi sekolah dalam tugasnya untuk mengembangkan lembaga." 11

Berdasarkan dan interview tersebut di atas maka dapat diketahui bahwa dalam memberlakukan bawahannya kepala sekolah dalam memberlakukan bawahannya sangatlah bagus sehingga mendapat kesan dirinya dan tugas-tugasnya mencapai tujuan.

4. Motivasi

Kepemimpinan kepala sekolah sebagai pemimpin pendidikan mempunyai stamina (daya kerja) dan antusias yang besar karena frustasi yang dihadapi oleh seseorang yang menjadi pelaksana biasa pada umumnya lebih kecil jika dibandingkan dengan frusasi oleh seseorang yang menduduki jabatan pimpinan. Kepemimpinan kepala sekolah berdasarkan pernyataan No.5 menunjukkan sesuai, yakni sebagai pemimpin pendidikan mempunyai daya kerja (stamina) dan mempunyai sifat keantusiasan yang besar dalam menjalankan tugasnya, karena masalah yang di hadapi oleh seseorang sebagai pelaksana, pada umumnya lebih kecil jika dibandingkan dengan masalah yang dihadapi oleh seseorang yang menduduki jabatan pimpinan.

Hal ini seperti yang diungkapkan oleh Bapak Drs. R. Djoko Suksmono, MM, yang menyatakan:

“..Kepemimpinan kepala sekolah di SMA YP 17 Surabaya ini memiliki kemampuan dalam menggerakkan bawahan ketika keadaan kurang bersemangat dan berdedikasi tinggi, yang akhirnya bawahan sadar akan kekurangan itu. Di samping itu juga kepemimpinan kepala sekolah dengan tekun membangkitkan kegairahan bekerja bagi bawahan yang frustasi dalam tindakan dan keputusan yang berakibatkan ketidak beresan dalam melaksanakan tugas. Sedangkan dalam hal penghargaan dan pujian terhadap bawahan yang cakap dan kretif kepala sekolah kurang memperhatikan.."22

Hasil intreview di atas, motivasi merupakan daya penggerak seseorang untuk mencapai hasil yang maksimal, tanpa adanya motivasi baik dari dalam maupun dari

${ }^{21}$ Hasil wawancara dengan Ibu Asri Mei Dini Hari, S.Pd, selaku Kepala SMA YP 17 Surabaya, pada Kamis, 05 April 2018.

22 Hasil wawancara dengan Bapak Drs. R. Djoko Suksmono, MM, selaku ketua Yayasan Pendidikan Tujuh Belas (YP 17) Surabaya, pada Senin, 02 April 2018. 
luar akan menyebabkan rendahnya kualitas kerja seseorang. Apalagi bagi seorang pemimpin harus tekun membangkitkan kegairahan bekerja bagi bawahan.

5. Pengambilan Keputusan

Dalam mengambil keputusan seorang pemimpin pendidikan selalu mempunyai keberanian dengan gemar dan cepat, terutama dalam keadaan darurat yang tidak dapat menunggu karena penundaan dalam mengambil keputusan pada hakekatnya merupakan suatu kelemahan yang tidak boleh dimiliki oleh seorang pemimpin yang baik. Kepala sekolah dalam mengambil keputusan selalu mempunyai keberanian dengan benar dan cepat, terutama dalam keadaan darurat. Dan tidak menunggu-nunggu atau penundaan dalam mengambil keputusan karena pada hakekatnya merupakan suatu kelemahan yang tidak boleh dimiliki oleh seorang pemimpin yang baik.

Berdasarkan hasil interview dengan guru SMA YP 17 Surabaya yang mengatakan bahwa keberanian kepala sekolah dalam mengambil keputusan itu dapatlah membawa sebuah lembaga menjadi maju dan berkembang seperti saat sekarang ini. ${ }^{23}$ Dari hasil interview tersebut di atas maka dapat diketahui bahwasannya keberanian dalam pengambilan keputusan itu yang ideal dimiliki oleh seorang pemimpin lembaga.

6. Keadilan

Seorang pemimpin pendidikan yang dalam menggerakan bawahannya selalu adil atas dasar kapasitasnya kerja bawahan itu, terlepas dari pendangan-pandangan kedaerahan, kesukuan, kepartaian, ikatan dan lain sebagainya

Kepala sekolah dalam menggerakkan bawahannya selalu bersikap adil, yakni atas dasar kapasitas kerjanya seperti halnya terlepas dari pandangan-pandangan kedaerahan, kesukuan, kepartaian, ikatan dan lain sebagainya dalam artian tidak ada perbedaan dalam menjalankan tugasnya.

“..Kepemimpinan Bu Asri selalu bersikap adil terhadap bawahannya yang dilihat dari segi kedaerahan, kepartaian dan lain sebagainya. Karena dengan sikap adil tersebut semua bawahannya merasa aman dalam menjalankan aktivitas kerjanya setiap hari.."24

Berdasarkan hasil interview tersebut, kepala SMA YP 17 Surabaya selalu memberikan agar bawahan lebih termotivasi dalam menjalankan tugasnya. Selanjutnya dalam mengambil keputusan kepala sekolah selalu menghormati dan

\footnotetext{
${ }^{23}$ Hasil wawancara dengan Bapak Drs. H. Nur Qomari, selaku guru di SMA YP 17 Surabaya, pada Senin, 09 April 2018.

${ }^{24}$ Hasil wawancara dengan Sumarni, S.Ag, MPd.I, selaku guru di SMA YP 17 Surabaya, pada Rabu, 11 April 2018. 
menghargai pendapat bawahan dan selalu berlaku adil atas dasar kapasitasnya kerja bawahannya, terlepas dari pandangan-pandangan kedaerahan, kesukuan, kepartaian, ikatan maupun yang lain apalagi menganakemaskan sesuatu bagian di dalam organisasi dan menganaktirikan yang lain.

7. Cara Melaksanakan Tugas

Kepemimpinan kepala sekolah ini dalam melaksanakan tugasnya dengan baik selalu dapat memusatkan perhatian, tindakan dan kebijaksanaannya, kepada pembinaan team work yang intim dan harmonis. Kepemimpinan kepala sekolah ini dalam menjalankan tugasnya selalu memusatkan perhatian tindakan dan kebijaksanaannya, kepada pembina team work yang intim dan harmonis. Terlebih lagi dengan hasil interview pada guru SMA YP 17 Surabaya yang mengatakan kepala sekolah sesalu bersikap demokratis terhadap bawahannya dalam yang ingin mengembangkan karier dengan memberikan jalan yang terbaik melalui kegiatankegiatan berbagai macam kegiatan di luar sekolah seperti seminar dan penataran. ${ }^{25}$

Berdasarkan dari pernyataan dan interview tersebut maka kepemimpinan kepala sekolah dalam menjalankan tugasnya selalu dapat memusatkan tindakan yang berdasarkan tanggung jawabnya sebagai pemimpin yakni dalam mengikutsertakan kegiatan seminar dan penataran yang berada di luar sekolah.

8. Sikap terhadap Bawahan

Kepala sekolah mempunyai kemampuan bergaul, ramah dan mampu mengahayati serta memahami sikap dan harapan bawahan. Karena dengan itu merupakan sifat yang miliki seorang pemimpin pendidikan di sekolah. Sedangkan kepala sekolah dalam menjalankan tugasnya sebagai pemimpin pendidikan dapat dan mampu bertindak sebagai penasehat, guru dan kepala terhadap bawahannya dan tergantung atas situasi masalah yang dihadapi. Dan pernyataan ini sesuai, bahwa sebagai pemimpin pendidikan yang baik selalu tidak menganakemaskan dan menganaktirikan sesuatu bagian dalam organisasi.

Sedangkan dilihat dari jaminan keamanan jiwa di tempat bekerja merupakan salah satu yang diperhatikan oleh kepala SMA YP 17 Surabaya. Hal ini sesuai dengan hasil interview dengan Bapak Winarto, BA, selaku Tata Usaha, berikut ini:

“..Kepala sekolah dapat menjamin keamanan jiwa, karena dapat dilihat dari seluruh bawahan merasa nyaman dalam menjalankan tugas-tugasnya. Terlebih, Beliau mampu mengahayati serta memahami sikap dan harapan bawahan." 26

25 Hasil wawancara dengan Bapak Drs. H. Nur Qomari, selaku guru di SMA YP 17 Surabaya, pada Senin, 09 April 2018.

${ }^{26}$ Hasil wawancara dengan Bapak Winarto, BA, selaku Tata Usaha di SMA YP 17 Surabaya, pada Sabtu, 14 April 2018. 
Hal ini sesuai dengan pendapat Bapak Didit Setiawan, selaku security di SMA YP 17 Surabaya, yang menyatakan bahwa kepemimpinan kepala sekolah diharapkan mempunyai sikap bergaul yang ramah dan memahami harapan bawahannya. ${ }^{27}$

Berdasarkan interview dengan kepala sekolah, guru dan karyawan SMA YP 17 Surabaya, maka penulis dapat mengetahui kelebihan kepemimpinan keplaa sekolah di SMA YP 17 Surabaya yang dapat dijadikan indikator pentingnya peran kepemimpinan di lembaga tersebut. Kepala sekolah di SMA ini dalam memberi semangat terhadap bawahan selalu berpijak bahwa manusia itu makhluk yang paling mulia serta mempunyai tanggung jawab yang tinggi terhadap tugas-tugas yang diberikan dan tugas terhadap bawahan. Selain itu juga mampu memberlakukan bawahan terhadap kesan dan tugas yang diberikan mempunyai arti penting terhadap tujuan institusional.

\section{Upaya Kepala Sekolah dalam Menunjang Penjaminan Mutu Lembaga}

Adapun upaya kepemimpinan kepala sekolah dalam menunjang penjaminan mutu lembaga SMA YP 17 Surabaya dapat diuraikan sebagai berikut:

1. Pengembangan Kurikulum

Kurilukum sangat berkaitan dengan proses belajar mengajar, untuk itu dalam proses belajar mengajar hendaknya SMA YP 17 Surabaya memilih strategi, metode dan teknik-teknik pembelajaran dan pengajaran yang paling efektif, sesuai dengan karakteristik mata pelajaran, karakteristik siswa, karakteristik guru, dan kondisi nyata sumber daya yang tersedia di sekolah dan lebih mengaktifkan siswa.

Berdasarkan wawancara dengan Ibu Asri Mei DH, S.Pd, selaku kepala sekolah yang menyatakan bahwa dalam pengembangan SMA YP 17 Surabaya dalam bidang kurikulum adalah dengan menerapkan kurikulum baru yakni Kurikulum 2013 (K-13). Adapun yang secara operasional pengembangan dalam kurikulum berkaitan dengan langkah-langkah antara lain: pendayagunaan fungsi dan tugas kepala sekolah, peningkatan kualitas guru, efisiensi dan efektifitas kegiatan belajar mengajar. ${ }^{28}$

Hal ini senada dengan Bapak Ruslan, BA, selaku Waka Kurikulum yang menyatakan:

“..Dalam pengembangan kurikulum yakni menyusun kurikulum yang meliputi kegiatan yang berhubungan dengan tugas guru dan berkaitan dengan proses belajar mengajar di

\footnotetext{
27 Hasil wawancara dengan Bapak Didit Setiawan, selaku security di SMA YP 17 Surabaya, pada Senin, 16 April 2018.

${ }^{28}$ Hasil wawancara dengan Ibu Asri Mei DH, S.Pd, selaku kepala SMA YP 17 Surabaya, pada Kamis, 19 April 2018. 
antaranya pembagian tugas mengajar pada guru, penyusunan silabus atau rencana pengajaran harian dan mingguan.."29

Administrasi kurikulum mencakup penyusunan kurikulum, pembinaan kurikulum, pelaksanaan kurikulum, seperti antara lain pembagian tugas mengajar pada guru, penyusunan silabus atau rencana pengajaran harian dan mingguan.

Kegiatan pengembangan kurikulum secara rinci dapat dikerjakan dalam kegiatan sebagai berikut: 1) Kegiatan yang berhubungan dengan tugas guru, meliputi: pembagian tugas mengajar, pembagian atau tanggung jawab dalam membina ekstrakurikuler dan koordinasi penyusunan persiapan mengajar; 2) Kegiatan yang berkaitan dengan proses belajar mengajar, meliputi: penyusunan jadwal mengajar, penyusunan program berdasarkan satuan waktu (semester dan tahunan), penyusunan daftar kemajuan murid, penyelenggaraan evaluasi belajar, laporan evaluasi dan egiatan bimbingan dan penyuluhan. ${ }^{30}$

Dari hasil wawancara tersebut, maka dapat diinterpretasikan bahwa di lembaga ini tidak hanya tugas guru dan kepala sekolah yang berusaha memperbaiki mutu pendidikan akan tetapi juga tugas dari pada bagian kurikulum sebagai pengendali PBM, dan juga pengatur jalannya pembelajaran. Dengan menerapkan kurikulum yang sesuai dengan perkembangan zaman dan sesuai dengan kebutuhan masyarakat, seperti menerapkan kurikulum baru yaitu K-13. Maka hal ini sangat menunjang dalam pengembangan lembaga pendidikan Islam di SMA YP 17 Surabaya dan tujuan yang diharapkan akan tercapai secara optimal.

2. Pengembangan Sumber Daya Manusia

Sumber daya manusia sebagai komponen yang terpenting dalam upaya peningkatan kualitas dan memerlukan perhatian yang pertama dan utama. Karena dalam pendidikan menyangkut masalah manusia yang selalu mengalami perkembangan dari waktu ke waktu. Terlebih sebagai makhluk sosial manusia memiliki kecenderungan secara kodrati untuk selalu berkelompok, dari kelompok inilah dinamisasi manusia akan tampak.

Lembaga pendidikan formal sebagai salah satu bentuk pengelompokan manusia yang harus bekerja sama dalam mencapai suatu tujuan. Dalam lembaga pendidikan terdapat sejumlah manusia atau tenaga yang sangat mempengaruhi pengembangan lembaga pendidikan Islam.

\footnotetext{
${ }^{29}$ Hasil wawancara dengan Bapak Ruslan, BA, selaku Waka Kurikulum SMA YP 17 Surabaya, pada Selasa, 24 April 2018.

30 Suryo Subroto, Dimensi-dimensi Administrasi Pendidikan di Sekolah (Jakarta: Bina aksara, 1984), 31.
} 
Berdasarkan wawancara dengan Ibu Asri Mei DH, S.Pd, berikut ini:

"Dalam pengembangan lembaga SMA YP 17 Surabaya, SDM merupakan isntrumen pertama dan utama. Upaya pemenuhan kebutuhan tenaga yang berkelayakan serta peningkatan SDM dalam arti peningkatan mutu profesionalisme. Hal ini mencakup antara lain: tenaga guru, tenaga administrasi, laboratotium, perpustakaan, tukang kebun." 31

Hal ini sesuai dengan pendapat Bapak Drs. R. Djoko Suksmono, MM, yang mengatakan bahwa dalam mengembangkan SDM terutama pada pendidik adalah dengan mengikutsertakan pelatihan dan pentaran yaitu MGMP yang digunakan untuk meningkatkan keprofesionalan seorang guru dalam mengajar. ${ }^{32}$

Berdasarkan pernyatan tersebut, maka dapat diinterpretasikan bahwa dalam pengembangan ketenagaan disini yang penulis peroleh dalam interview dengan kepala sekolah dan ketua YP 17 bahwasannya di SMA YP 17 Surabaya dalam pengembangan dan peningkatan mutu ketenagaan yang ada di sekolah tersebut berusaha akan lebih baik demi peningkatan mutu profesionalisme guru.

Sedangkan pada pengembangan siswa SMA YP 17 Surabaya yang nantinya diarahkan pada pengembangan potensi:

“..Pembinaan akhlakul karimah, pembinaan intelegensi dan prestasi keilmuan serta pembinaan kreatifitas siswa. Sedangkan kegiatan ekstrakurikuler yang dilaksanakan untuk pembinaan biang kesiswaan antara lain: pembacaan seni baca Al-qur'an, kegiatan ketrampilan kepramukaan dan kegiatan lain-lainnya.."33

Dari hasil wawancara dengan tersebut di atas, dapat penulis diskripsikan bahwa dalam bidang kesiswaan disini pelayanan siswa tidak hanya di mulai dari penerimaan siswa baru saja, akan tetapi juga menyangkut pengembangan, pembinaan, pembimbingan di sekolah, dan disini di tuntut semua pihak turut serta dalam mendidik perkembangan siswa.

Sekolah merupakan lembaga pendidikan yang menjadi cermin peradaban bangsa. Fungsi dan tugasnya adalah merealisasikan cita-cita masyarakat yang menginginkan agar anak-anak didiknya menjadi manusia yang beriman dan berilmu pengetahuan. Dalam rangka upaya meraih hidup sejatera duniawi dan kebahagiaan hidup di akhirat. Untuk mencapai tujuan tersebut diperlukan profesionalisme.

\footnotetext{
31 Hasil wawancara dengan Ibu Asri Mei DH, S.Pd, selaku kepala SMA YP 17 Surabaya, pada Kamis, 19 April 2018.

32 Hasil wawancara dengan Bapak Drs. R. Djoko Suksmono, MM, selaku ketua Yayasan

Pendidikan Tujuh Belas (YP 17) Surabaya, pada Kamis, 19 April 2018.

33 Hasil wawancara dengan Bapak Drs. Heru Santoso, M.Pd, selaku Waka Kesiswaan SMA YP 17 Surabaya, pada Rabu, 18 April 2018.
} 


\section{Pengembangan Sarana dan Prasarana}

Sarana prasarana merupakan factor penting dalam melaksanakan kegiatan proses belajar mengajar karena dalam kegiatan tersebut tanpa adanya sarana prasarana yang menunjang tidak dapat berjalan sesuai dengan tujuan pendidikan.

“..Pengembangan sarana dan prasarana yang dilakukan SMA YP 17 Surabaya yaitu berupa perangkat keras maupun perangkat lunak, semisal: pengadaan pembangunan sarana dan prasarana baru secara bertahap dan terencana rehabilitasi sarana dan prasarana yang ada, melengkapi buku-buku pelajaran dan perpustakaan sekolah, pengembangan dan perbaikan laboratorium secara lengkap, penyediaan alat-alat pelajaran yang berupa media penyediaan oleh raga, komputer serta kelengkapan alatalat ekstrakurikuler baik kepramukaan dan usaha kesehatan sekolah." ${ }^{34}$

Selaras dengan pendapat Ibu Asri di atas, Ibu Dra. Sukarminah, selaku Waka Sarpras, mengatakan:

“..Sarana dan prasarana di SMA YP 17 Surabaya ini sangatlah perlu dikembangkan seperti halnya sarana sekolah meliputi semua peralatan serta perlengkapan yang langsung digunakan dalam proses pendidikan di sekolah, misalnya: gedung sekolah, ruangan, meja kursi, dan alat peraga dan lain-lain sedangkan prasarana merupakan semua komponen yang secara tidak langsung menunjang jalannya proses belajar mengajar atau pendidikan di sekolah, misalnya: jalan menuju ke sekolah, halaman sekolah, tata tertib sekolah dan sebagainya.."35

Hal ini sesuai dengan pendapat Oteng Sutrisna, yang menyatakan bahwa sarana dan prasarana merupakan bagian dari alat pendidikan yang sangat penting gunan menunjang keberhasilan pendidikan. Oleh karena itu, perlu adanya pengelolaan pendidikan yang baik, sebagaiman dikatakan bahwa suatu sekolah dapat berhasil atau berjalan dengan baik dan lancar apabila pengelolaan sarana dan prasarana itu baik. ${ }^{36}$ Agar sekolah dapat melaksanakan kegiatan-kegiatan dalam rangka menunjang proses belajar dan mengajar pendidikan dengan baik, maka perlu adanya sarana dan prasarana yang representatif.

Berdasarkan hasil wawancara dan dikaitkan dengan pendapat di atas, maka dapat diinterpretasikan bahwa sarana dan prasarana sangat penting dan sangat membantu dalam proses belajar mengajar, sebagai langkah perbaikan agar lebih baik dan dapat membantu siswa dalam belajarnya.

\section{Pengembangan Keikutsertaan Masyarakat}

Hubungan sekolah dan masyarakat adalah suatu proses komunikasi antara sekolah dan masyarakat dengan maksud meningkatkan pengertian warga

\footnotetext{
${ }^{34}$ Hasil wawancara dengan Ibu Asri Mei Dini Hari, S.Pd, selaku Kepala SMA YP 17 Surabaya, pada Kamis, 26 April 2018.

${ }^{35}$ Hasil wawancara dengan Ibu Dra. Sukarminah, selaku Waka Sarana dan Prasarana SMA YP 17 Surabaya, pada Kamis, 26 April 2018.

${ }^{36}$ Oteng Sutrisna, Administrasi Pendidika; Dasar Teori untuk Praktek Profesional (Bandung: angkasa, 1987$), 77$.
} 
masyarakat tenatng kebutuhan dan praktek pendidikan serta mendorong minat dan kerja sama dalam usaha memperbaiki sekolah.

Masyarakat di samping sebagai objek yang harus diperhitungkan oleh lembaga mereka juga berperan sebagai subjek yang berhak untuk menilai dan mennetukan pilihannya sendiri, tentunya ke depan lembaga pendidikan (sekolah) harus lebih dahulu memiliki kesiapan yang sempurna, realistis dan profesional dalam mengelolanya. Berikut hasil wawancara penulis dengan dengan Ibu Asri:

“..Dalam hal ini hubungan masyarakat SMA YP 17 Surabaya mengupayakan partisipasi masyarakat yang dapat menunjang peningkatan dan pengembangan sekolah antara lain: peningkatan peran serta orang tua siswa melalui komite sekolah, meningkatkan kerjasama dan jalinan hubungan baik dengan instansi terkait seperti DIKNAS dan pemerintah daerah, termasuk KKM (kelompok kerja sekolah). Selain itu, lembaga menjalin hubungan dengan tokoh-tokoh masyarakat dan para ulama setempat, mengupayakan dana beasiswa bagi siswa yang tidak mampu, mengikutsertakan siswa dalam kegiatan-kegiatan kemasyarakatan." ${ }^{37}$

Dari hasil wawancara tersebut di atas, bahwasannya peran masyarakat itu sangat penting untuk meningkatkan keterlibatan, kepedulian, kepemilikan dan dukungan dari masyarakat terutama dukungan moral dan finansial yang sehubungan dengan adanya kurikulum baru yang diimplementasikan, hubungan sekolah dengan masyarakat yang perlu ditingkatkan terutama dalam meningkatkan dan mengembangkan potensi-potensi yang dimiliki oleh sekolah dan daerah serta potensi yang dimiliki oleh sekolah dan daerah serta potensi peserta didik secara keseluruhan.

Hubungan antara sekolah dengan masyarakat penting untuk direalisasikan dengan berbagai bentuk dan cara pelaksnaannya. Beberapa bentuk atau cara yang telah dikenal adalah: Open door politics, atau pembinaan kesempatan pada orang tua murid berkunjung ke sekolah untukmembicarakan sekolah khususnya yang terjadi pada anaknya, home visiting atau kunjungan sekolah ke rumah murid, penggunaan resources persons, dan pengadaan serta mengefektifkan Badan Pembantu Penyelenggaraan Pendidikan yang disingkat dengan BP3.

Adapun tujuan dari hubungan sekolah dengan masyarakat anyak sekali, tetapi tujuan pokoknya adalah mengembangkan kualitas belajar dan pertumbuhan anak-anak, meningkatkan tujuan dan kualitas kehidupan masyarakat, mengembangkan pengertian, antusiasme masyarakat dalam membantu pendidikan yng diselenggarakan oleh pemerintah. Hal tersebut menjadikan tolak ukur bahwa

\footnotetext{
37 Hasil wawancara dengan Ibu Asri Mei Dini Hari, S.Pd, selaku Kepala SMA YP 17 Surabaya, pada Jum’at, 27 April 2018.
} 
dalam hubungannya antara sekolah dan masyarakat sangatlah penting dalam mengembangkan dan meningkatkan sekolah seperti apa yang diinginkan masyarakat.

Dalam setiap kepemimpinan tentu terdapat kelemahan atau kekurangan. Tidak terkecuali dengan kepemimpinan kepala sekolah di SMA YP 17 Surabaya yang dapat deskripsikan bahwa masih dijumpai sebagian guru dan karyawan yang menyatakan bahwa sikap kepala SMA YP 17 Surabaya kurang memperhatikan terhadap bawahan yang cakap dan kreatif, serta sikap bergaul yang ramah dan memahami harapan bawahan. Di samping itu juga kepala sekolah di SMA YP 17 Surabayakurang dalam memberikan teguran dan bimbingan terhadap bawahan yang kurang mampu bekerja.

Setelah diketahui kelebihan dan kekurangan kepemimpinan kepala sekolah di SMA YP 17 Surabaya, selanjutnya untuk menentukan tingkat kualitas dan tidaknya kepemimpinan kepala sekolah tersebut, dilakukan penilaian terhadap angket kepala sekolah, interview guru dan karyawan mengenai seputar kemampuan dan ketrampilan sebagai indikator tindakan-tindakan di dalam melaksanakan tugas sebagai “Educational Leader" tentang kebijaksanaannya.

Dengan demikian sesuai pembahasan sebelumnya dapat dianalisis bahwa kepemimpinan kepala sekolah di SMA YP 17 Surabaya dalam menjalankan pendidikan dan pengajaran di sekolah dalam kategori baik dengan didukung berbagai aspek dan unsur yang terkait seperti adanya bawahan yang kreatif memberikan kritik membangun demi tercapainya tujuan bersama yaitu tujuan institusional lembaga pendidikan sekolah di SMA YP 17 Surabaya.

Berdasarkan paparan di atas, maka peran kepemimpinan kepala sekolah ini sebenarnya telah didasarkan kemampuannya untuk melaksanakan tugas itu dengan baik. Seorang pemimpin, dalam argumen Gemmill dan Oakley, harus memiliki ciriciri sebagai berikut: ${ }^{38}$ 1) Berpengetahuan luas; 2) Mempunyai keyakinan bahwa organisasi akan berhasil mencapai tujuan yang telah ditentukan melalui dan berkat kepemimpinannya; 3) Mengetahui dengan jelas sifat hakiki dan kompleksitas dari pada tujuan yang hendak dicapai; 4) Memiliki stamina (daya kerja) dan entusiasme yang besar; 5) Gemar dan cepat engambil kepuusan; 6) Objektif dalam arti dapat menguasai emosi dan lebih banyak mempergunakan rasio; 7) Adil dalam memperlakukan bawahan; 8) Menguasai prinsip-prinsip human relations;

38 G. Gemmill \& J. Oakley, “Leadership: An alienating social myth?” Human Relations, Vol. 45 No. 2 (1992): 113-129. 
9)Menguasai teknik-teknik berkomunikasi; 10) Dapat dan mampu bertindak sebagai penasehat, guru dan kepala terhadap bawahannya tergantung atas situasi dan masalah yang dihadapi; 11) Mempunyai gambaran yang menyeluruh tentang semua aspek kegiatan organisasi.

Dari karakter yang diuraikan di atas, maka dapat menjadi ukuran bagi peran kepemimpinan kepala sekolah dalam menunjang penjaminan mutu SMA YP 17 Surabaya. Dalam menunjang penjaminan mutu lembaga, kepala SMA YP 17 sangat concern pada pengembangan kurikulum, sarana prasarana, sumber daya manusia (pendidik, siswa, pegawai) dan peran serta masyarakat. Dari usaha yang dilakukan oleh kepala sekolah ini, merupakan usaha yang signifikan yang dilakukan melalui perencanaan yang sangat matang dalam menunjang dan mengembangkan mutu lembaga. Maka, dapat disimpulkan bahwa peran kepemimpinan kepala sekolah merupakan elemen paling esensial dalam sebuah lembaga pendidikan. Dalam kepemimpinannya, kepala SMA YP 17 Surabaya mempunyai tanggung jawab sebagai mediator, dinamisator, katalisator, motivator maupun sebagai motor penggerak bagi komunitas yang dipimpinnya.

\section{E. Kesimpulan}

Dari deskripsi yang telah penulis uraikan pada bagian sebelumnya, maka penulis simpulkan penelitian ini sebagai berikut: Pertama, peran kepala sekolah dalam meningkatkan mutu SMA YP 17 Surabaya dilakukan dengan tanggung jawab yang kuat, keberanian dalam mengambil keputusan, dan keikutsertaan dalam melaksanakan kebijakan. Kedua, dalam menunjang penjaminan mutu lembaga, kepala SMA YP 17 mengarusutamakan pengembangan kurikulum, sarana prasarana, sumber daya manusia (pendidik, siswa, pegawai) dan peran serta masyarakat. Upaya tersebut dilakukan dengan adanya perencanaan yang sangat matang dalam mengupayakan pengembangan SMA YP 17 Surabaya. Namun demikian, kepala SMA YP 17 Surabaya harus melakukan evaluasi secara periodik dari setiap program yang telah dilaksanakan. Tujuannya adalah untuk mengukur tingkat keberhasilan dan mengetahui kekurangan program yang dilaksanakan. Selanjutnya, kepala SMA YP 17 perlu melakukan sosialiasi lembaga yang lebih massif kepada masyarakat. Hal ini sebagai upaya untuk meningkatkan partisipasi masyarakat dalam upaya pengembangan mutu sekolah ke depan. 


\section{F. Referensi}

Adler, M., et., al, Devolved school management in secondary schools in Scotland (Edinburgh: Department of Politics, University of Edinburgh, 1997).

Ahmadi, R. Pengantar Pendidikan. Yogyakarta: Ar-Ruzz Media, 2015.

Astin, Alexander., Achieving Educational Excellence. San Francisco: Jossey Bass, Inc Publishers, 1985.

AR, Zaini Tamin. "PESANTREN DAN POLITIK (Sinergi Pendidikan Pesantren Dan Kepemimpinan Dalam Pandangan KH. M. Hasyim Asy'ari)", Jurnal Pendidikan Agama Islam (Journal of Islamic Education Studies), Vol. 3, No. 2 (2015).

AR, Zaini Tamin. “Dinamika Perkembangan Kurikulum Pendidikan Pesantren; Satu Analisis Filosofis", EL-BANAT: Jurnal Pemikiran dan Pendidikan Islam, Vol. 8 No. 1 (2018): 1-21.

Bromley, D. Reputation, image, and impression management. Wiley: 1993.

Budianto, Nanang. "Kepemimpinan Pendidikan dalam Total Quality Management", Jurnal Falasifa Vol. 2 No. 1 (2011).

European Commission. Assuring Quality in Education: Policies and Approaches to School Evaluation in Europe. Eurydice Report. Luxembourg: Publications Office of the European Union, 2014).

Gemmill, G., \& Oakley, J. “Leadership: An alienating social myth?” Human Relations, Vol. 45 No. 2 (1992): 113-129.

Indrafachrudi, Soekarto. Pengantar Bagaimana Memimpin Sekolah Yang Baik. JKT: Ghalia Indonesia, 1994.

Kartono, Kartini. Pemimpin Dan Kepemimpinan. Jakarta: Rajawali, 1986.

Mukhtar. "Strategi Kepala Sekolah Dalam Meningkatkan Kinerja Guru Pada Smp Negeri Di Kecamatan Masjid Raya Kabupaten Aceh Besar”, Jurnal Magister Administrasi Pendidikan, Volume 3, No. 3, (Agustus 2015).

Mulyasa.E. Kepala Sekolah Profesional Dalam Konteks Menyukseskan MBS Dan KBK. Bandung: PT. Remaja Rosda Karya, 2003.

N. Andrew Cohen \& Jeewhan Yoon. "Who Makes Whom Charismatic? Leadership Identity Negotiation in Work Teams", Journal of Leadership \& Organizational Studies, Vol. 28 Issue 1, February 2021.

Nawawi, Hadari. Administrasi Pendidikan. Jakarta: Gunung Agung, 2002.

Poster, Cyril. Gerakan Menciptakan Sekolah Unggul. Jakarta: Lembaga Indonesia Adidaya, 2000.

Robbins, S. P. Organizational behavior: Concepts, Controversies, applications (8th ed). Upper Sadlle River, NJ: Prentice-Hal, 1998. 
Subroto, Suryo. Dimensi-Dimensi Administrasi Pendidikan Di Sekolah. Jakarta: Bina Aksara, 1984.

Suprayogo, Imam. Pendidikan Berparadigma Al-Qur'an Cet I. Malang: Aditya Media Bekerja Sama Dengan UIN Malang Press, 2004.

Sutisna, Oteng. Administrasi Pendidikan Dasar Teori Untuk Praktek Profesional. Bandung: Angkasa, 1987. 